\title{
MIMOSA TENUIFLORA FOR THE TREATMENT OF DAMAGED SKIN - STUDY ON ITS EFFICACY AND TOLERABILITY IN THE TREATMENT OF IRRITATIVE CONTACT DERMATITIS
}

\author{
ALIN CODRUȚ NICOLESCU ${ }^{1 \#}$, ANCA CECILIA NICOARĂ ${ }^{2 *}$, SÎNZIANA IONESCU ${ }^{2,3 \#,}$ \\ LAURENȚIU SIMION $^{2,3}$, MARIA MAGDALENA CONSTANTIN ${ }^{2,4 \#}$, ȘTEFANA BUCUR ${ }^{2,4}$, \\ IOAN ANCUT,A ${ }^{2,5}$
}

${ }^{1}$ Roma Medical Centre for Diagnosis and Treatment, 32-34 Roma Street, Bucharest, 011773, Romania

2 “Carol Davila” University of Medicine and Pharmacy, 37 Dionisie Lupu Street, Bucharest, 050474, Romania

${ }^{3}$ Surgery Department I, "Prof. Dr. Al. Trestioreanu”, Oncology Institute Bucharest, 252 Fundeni Road, Bucharest, 022328, Romania

${ }^{4}$ Dermatology Department II, Colentina Clinical Hospital, 19-21 Ștefan cel Mare Road, Bucharest, Romania

${ }^{5}$ Department of Rheumatology, "Dr. I. Cantacuzino" Clinical Hospital, 5-7 Ioan Movilă Street, Bucharest, 020475, Romania

*corresponding author: anca.nicoara@umfcd.ro

${ }^{\#}$ Authors with equal contribution.

\begin{abstract}
In the context of a striking increase in the number of Irritative Contact Dermatitis (ICD) cases during the challenging COVID-19 pandemic, between March -July 2020, especially among healthcare professionals, we assessed the efficiency of a commercially available barrier cream applied 2 times/day for 1 week. The barrier cream tested is based on Mimosa tenuiflora, an extract from the bark of the tree also known as the "skin tree". This extract contains many components that participate in all phases of wound healing by accelerating the cicatrisation process and reducing the risk of scarring. The study consisted in visual scoring of the skin condition (analysing xerosis, erythema, scaling and cracks) during the $1^{\text {st }}$ visit and then after 7 days $\left(2^{\text {nd }}\right.$ visit). Patients were also asked to rate the prickling and burning sensation, pain and pruritus, at the same intervals. After 7 days of treatment a Satisfaction Questionnaire was also filled in. The results showed a statistically significant reduction $(\mathrm{p}<0.0002)$ in all targeted parameters, as well as a perception of excellent efficacy and tolerability. The barrier cream tested is a valuable dermato-cosmetic treatment option for ICD.
\end{abstract}

\section{Rezumat}

În contextul creșterii numărului de cazuri de dermatită de contact iritativă (DCI) în timpul pandemiei COVID-19 (perioada martie - iulie 2020), în special în rândul profesioniștilor din domeniul sănătății, am evalut eficacitatea unei creme barieră disponibile comercial, aplicată de 2 ori/zi timp de 1 săptămână. Crema testată se bazează pe Mimosa tenuiflora, un extract din scoarța copacului cu nume omonim. Acest extract conține componente care intervin în toate fazele vindecării rănilor prin accelerarea etapelor reparatorii și reducerea riscului de apariție a cicatricilor. Studiul a constat în analizarea vizuală inițială, a stării pielii afectate de DCI (urmărind xeroza, eritemul, descuamarea și fisurile) și apoi după 7 zile. De asemenea pacienților li s-a cerut să evalueze senzaţia de înţepătură, arsură, durere şi prurit, la aceleași intervale. După 7 zile de tratament a fost completat un chestionar de satisfacție a pacientului referitor la preparatul utilizat. Rezultatele analizei au arătat o reducere semnificativă statistic $(\mathrm{p}<0,0002)$ a tuturor parametrilor vizați, precum și o percepție de eficacitate și tolerabilitate excelentă asupra preparatului. Crema barieră testată este o opțiune valoroasă în tratamentul dermato-cosmetic al DCI.

Keywords: Mimosa tenuiflora, wound healing, anti-inflammatory, antimicrobial, barrier cream, irritative contact dermatitis

\section{Introduction}

Irritative Contact Dermatitis (ICD) is a condition that appears as a rash, caused by exogenic factors. The acute form of this condition may be described as erythema, infiltration, blistering, with xerosis, scaling and cracking of the skin becoming more pronounced in its chronic form [1].

A key feature of chronic ICD is the exposure to a specific irritant that results in disruption of the epidermal barrier, specifically the stratum corneum. The epidermal damage will then facilitate trans- epidermal water loss due to increased skin permeability [2], keratinocyte release of proinflammatory cytokines, and involvement of the innate immune system [3]. Healthcare professionals in the front line of COVID19 pandemic response are most in danger of developing ICD due to frequent hand hygiene and protective equipment. In a single centre, cross sectional study conducted in an Irish hospital, 82.6\% of 260 health care workers reported symptoms of ICD, during April and May 2020. The hands were the most commonly affected site $(76.47 \%)$ and the most frequently reported 
symptom was dry skin (75.37\%) [4]. Handwashing alone is not the only contributor, as further data from China reported the detrimental role played by N95 masks [5].

Also, a study published by Chiriac et al. established that $\mathrm{Cd}$ and $\mathrm{Ca}$ detected on the inner surface of powder free latex gloves used by healthcare professionals contributed to the toxicity to the skin that led to work-related occupational hand eczema [6].

Seeing the striking increase in the number of ICD cases during the challenging COVID-19 pandemic (March - May 2020), we decided to assess the efficacy of a new barrier cream designed to isolate and repair damaged skin following exposure to the aggressive action of external irritative substances, allergens, particulate pollutants. Our goal was to investigate its efficacy considering the growing number of ICD cases, particularly among healthcare professionals during the above-mentioned period. The tested barrier cream was created around a key ingredient known for its properties in repairing damaged skin - Mimosa tenuiflora extract.

In a massive explosion resulting in a high number of burnt patients and in the powerful earthquake of 1985, the Mexican Red Cross used the Mimosa tenuiflora extract because it was known to repair damaged skin [7]. The extract showed: analgesic effect in less than 3 hours and full reconstruction of the epidermis in 3-5 weeks, repigmentation in 3 months. Over 6000 testimonies were collected of which 3000 were from the Tlanelplana Hospital, throughout 3 years. Statistically, $20 \%$ of the badly burnt patients do not survive despite modern treatments. The Mexican Red Cross claimed that this percentage dropped to $4 \%$ with the use of Mimosa tenuiflora [8].

A study on Mimosa tenuiflora extract conducted by the Pasteur laboratories from Strasbourg isolated and identified three new triterpenoid saponins (mimonosids A, B and C), three steroidal saponins (3-O-beta-D-glucopyranosyl campesterol, 3-O-betaD-glucopyranosyl stigmasterol and 3-O-beta-Dglucopyranosyl beta-sitosterol) along with lupeol, campesterol, stigmasterol and beta-sitosterol [9]. All these new 6 saponins were isolated for the first time from Mimosa tenuiflora. The 3 new triterpenoid saponins have been subject to biological and in vitro tests (immune modulation and proliferation) using various cultures of animal and human cells. The results of these tests played a part in explaining the efficacy of its traditional use.

A large quantity of tannins was detected in the Mimosa tenuiflora bark, with almost $70 \%$ of the condensed tannins being found in the methanol extract [10]. Many of the components of this natural extract were then studied individually, which confirmed its various effects: antimicrobial [11], antimycotic [12], astringent
[13], anti-aflatoxin B1 activity related to strong antioxidative capacity [14].

This extract is also essential because of its complex composition which acts in all 3 phases of wound healing: inflammation, cellular proliferation and tissue remodelling (some authors describe 4 phases, with haemostasis being described separately, although it is part of the inflammatory phase).

These phases last from 1 - 5 minutes (tannins/ haemostasis) to 30 - $60 \mathrm{~min}$ for some flavonoids and saponins/inflammation, from 1 - 24 hours (alkaloids, saponins, lupeol/inflammation), to 2 - 14 days (phytosterols, chalcones/cellular proliferation), to weeks and months (through arabinogalactans, saccharides, lipids/tissue remodelling). The composition and long-lasting action explain the skin repairing properties of Mimosa tenuiflora, as proven by clinical studies on venous leg ulcers [15] or nipple fissures [13], and when combined with a film-coating agent, it heals wounds and regenerates the skin [16].

Another important ingredient of the barrier cream is a complex of natural biopolymers (galactomannans and galactan sulphates), which form a durable, flexible and non-occlusive film on the surface of the skin, mimicking its properties and functions and reducing the adhesion to the skin of external irritative substances, allergens and particulate pollutants. The biopolymeric film increases skin defence capability against mechanical aggression.

The objective of the study was to assess the reduction of inflammatory events and the repair of damaged skin following constant application of the tested barrier cream, based on the scores given by the physician and patient for targeted symptoms, as well as to assess the perception of efficacy and tolerability among the patients enrolled in the study based on the Patient Satisfaction Questionnaire.

\section{Materials and Methods}

Initially 20 patients were enrolled in the study, 2 of the patients drop-out the study, the final sample included 18 patients ( 9 males and 9 females with an average age of 42.77 years). Except for one child aged 12 years old diagnosed with ICD on one leg, and another child aged 14 years old diagnosed with ICD on one ear, the other patients were adults, mostly fellow physicians who visited the exam room with ICD on their hands, inflicted, most likely, by frequent handwashing and disinfecting. The cause of ICD in one of the children was, most likely, the contact with a plant during a field trip. The second child, known to have a history of atopy, developed ICD on the right ear after prolonged use of the cell phone, also while being away from home. Cell phones contain metals and are a potential source of exposure. 
FARMACIA, 2021, Vol. 69, 5

Table I

Group characteristics

\begin{tabular}{|l|c|}
\hline \multicolumn{1}{|c|}{ Patients enrolled } & 18 \\
\hline Average age (years) & 42.77 \\
\hline Min. age (years) & 12 \\
\hline Max. age (years) & 60 \\
\hline Sex (male/female) & $50 \% / 50 \%$ \\
\hline
\end{tabular}

Study design

The trial was carried out between March - July 2020 at Roma Medical Centre for Diagnosis and Treatment, Bucharest, Romania. The study was conducted according to the WMA Declaration of Helsinki - Ethical Principles for Medical Research involving Human Subjects (1975), last amended in Brazil, in October 2013, and it was approved by the Institutional Ethics Committee. Once the physician established whether a subject was eligible, the adult patients and the children' parents received information about the protocol and signed the Consent Form. The study consisted in several steps: the $1^{\text {st }}$ Visit $(D 0)$ : patient examination and collection of demographic and therapeutic data; filling in the form by the physician (rating the level of xerosis, erythema, severity of exfoliation, cracks); filling in the form by the patient (rating the sensation of prickling, burn, pain, pruritus); the scores were distributed on a rating scale from $0-4$ $(0=$ absent 1 = discrete; $2=$ mild; $3=$ moderate $; 4=$ severe/marked) for the targeted parameters; application of the barrier cream by the patient on the damaged skin area, as instructed by the physician (first application); the adult patients were instructed to use the cream two times per day, before and after work; the paediatric patients were instructed to apply the cream in the morning and in the evening, after gentle cleansing the affected area. The $2^{\text {nd }}$ Visit (D7): the patient came to the examination room 7 days from 1st visit, after exclusively applying the barrier cream provided ( 2 applications/day); the patient was examined, and both the physician and the patient filled in the abovementioned forms, rating again the targeted parameters; the patient filled in the Satisfaction Questionnaire rating the perceived efficacy and tolerability of the tested product.

Statistical analysis

Data were collected using an Excel spread sheet (Microsoft Corp., Redmond, WA, USA) and analysed using SPSS software (V25; IBM SPSS, Armonk, NY, USA). The analysis of the variation between baseline ratings and average subsequent ratings was determined using the Mann - Whitney test (also known as the Mann-Whitney-Wilcoxon test), which is the equivalent of the parametric independent t-test, deemed appropriate considering the size of the data lot.

\section{Results and Discussion}

This study showed the improvement in the skin condition resulting from the repeated use of the barrier cream tested. Thus, protection against further irritation as well as significant rehydration and visible regeneration of the skin was achieved in this 1-week use-test.

Physician's assessment of treatment efficacy

The physician scored the objective parameters: xerosis, erythema, severity of scales, cracks in the skin areas affected by ICD between D0 and D7. When hands areas were the affected, the scores registered were the average scores between right and left hand. The results are presented in Table II.

Table II

ICD scores for the objective parameters

\begin{tabular}{|l|c|c|c|c|c|}
\hline Time & n & Mean \pm SD & Median & Min. & Max. \\
\hline \multicolumn{7}{|c|}{ Xerosis* } \\
\hline D0 & 18 & $3.31 \pm 0.86$ & 4.00 & 2.0 & 4.0 \\
\hline D7 & 18 & $0.47 \pm 0.61$ & 0.00 & 0.0 & 2.0 \\
\hline \multicolumn{7}{|c|}{ Erythema* } \\
\hline D0 & 18 & $3.19 \pm 0.94$ & 3.50 & 1.0 & 4.0 \\
\hline D7 & 18 & $0.22 \pm 0.43$ & 0.00 & 0.0 & 1.0 \\
\hline \multicolumn{7}{|c|}{ Scaling* } \\
\hline D0 & 18 & $3.42 \pm 0.73$ & 4.00 & 2.0 & 4.0 \\
\hline D7 & 18 & $0.47 \pm 0.63$ & 0.00 & 0.0 & 2.0 \\
\hline \multicolumn{7}{|c|}{ Cracking* } \\
\hline D0 & 18 & $2.78 \pm 1.07$ & 2.75 & 1.0 & 4.0 \\
\hline D7 & 18 & $0.39 \pm 0.63$ & 0.00 & 0.0 & 2.0 \\
\hline * p $\leq 0.05$
\end{tabular}

After 7 days of applying the barrier cream provided, all the physician's scores for the targeted objective parameters significantly decreased, with no individual values above 2 , corresponding to an efficacy above $85 \%$, thus showing a good response to the treatment. The average score for xerosis significantly decreased by -2.83 points $(-85.7 \%$; $\mathrm{p}=0.00018)$ on D7 $(0.47)$ as compared to D0 (3.31). Erythema: reduction of -2.97 points $(-93.0 \%$; $\mathrm{p}=0.00018)$ on $\mathrm{D} 7(0.22)$ as compared to D0 (3.19). Scales: decrease of -2.94 points $(-86.2 \% ; \mathrm{p}=0.00018)$ on D7 (0.47) as compared to D0 (3.42). Cracks: decrease of -2.39 points $(-86.0 \%$; $\mathrm{p}=0.00017)$ on D7 (0.39) compared to D0 (2.78) (Figures 1, 2, 3 and 4).

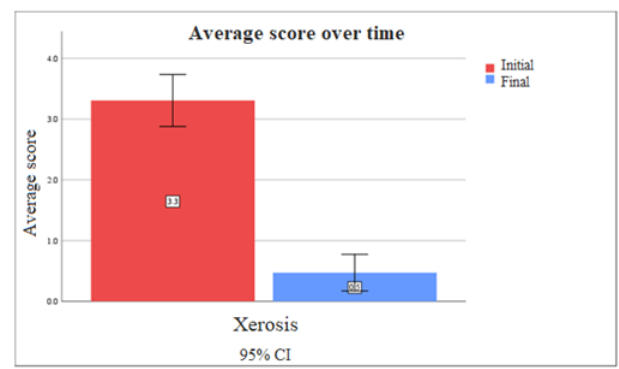

Figure 1.

Scores for xerosis 
FARMACIA, 2021, Vol. 69, 5

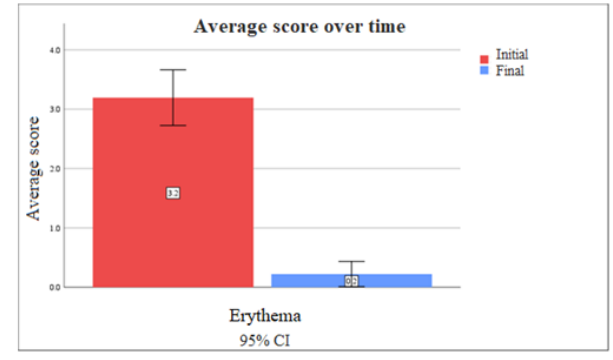

Figure 2.

Scores for erythema

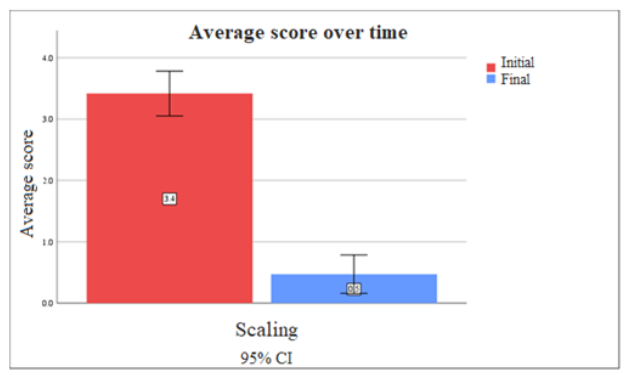

Figure 3.

Scores for scaling

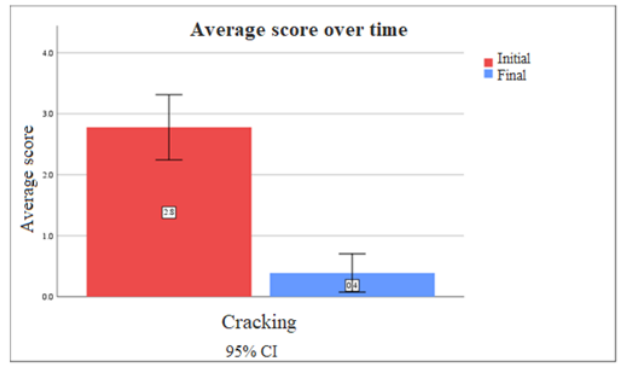

Figure 4.

Scores for cracking

Patient's assessment of treatment efficacy

The patients scored the subjective parameters: prickling sensation, burn, pain, pruritus in the skin areas affected by ICD at D0 and D7. When hands were the affected areas, the scores registered were the average scores between right and left hand. The results are summarized in Table III.

Table III

ICD scores for the subjective parameters

\begin{tabular}{|c|c|c|c|c|c|}
\hline Time & n & Mean \pm SD & Median & Min. & Max. \\
\hline \multicolumn{7}{|c|}{ Prickling sensation* } \\
\hline D0 & 18 & $3.61 \pm 0.70$ & 4.00 & 2.0 & 4.0 \\
\hline D7 & 18 & $0.36 \pm 0.64$ & 0.00 & 0.0 & 2.0 \\
\hline \multicolumn{7}{|c|}{ Burning* } \\
\hline D0 & 18 & $3.58 \pm 0.73$ & 4.00 & 2.0 & 4.0 \\
\hline D7 & 18 & $0.22 \pm 0.39$ & 0.00 & 0.0 & 1.0 \\
\hline \multicolumn{7}{|c|}{ Pain* } \\
\hline D0 & 18 & $3.19 \pm 0.75$ & 3.00 & 2.0 & 4.0 \\
\hline D7 & 18 & $0.22 \pm 0.43$ & 0.00 & 0.0 & 1.0 \\
\hline \multicolumn{7}{|c|}{ Pruritus* } \\
\hline D0 & 18 & $3.06 \pm 0.91$ & 3.00 & 1.5 & 4.0 \\
\hline D7 & 18 & $0.28 \pm 0.55$ & 0.00 & 0.0 & 2.0 \\
\hline * $\leq 0.05$
\end{tabular}

After 7 days of applying the barrier cream provided, all the patients' scores for the targeted subjective parameters significantly decreased, with no individual values above 2 , corresponding to an efficacy above $90 \%$.

The mean score for the prickling sensation reported a significant decrease of -3.25 points $(-90.0 \%$; $\mathrm{p}=$ $0.00016)$ on D7 (0.36) as compared to D0 (3.61). The burning sensation: decreased by -3.36 points (93.8\%; $\mathrm{p}=0.00016)$ on D7 $(0.22)$ as compared to D0 (3.58). Pain: decrease of -2.97 (-93.0\%; $\mathrm{p}=$ $0.00015)$ on D7 (0.22) as compared to D0 (3.19). Pruritus: decrease of $-2.79(-90.9 \% ; \mathrm{p}=0.00018)$ on D7 (0.28) versus D0 (3.06). These data were correlated with the efficacy perception, as reported by patients in the Satisfaction questionnaire at the end of the study (Figures 5, 6, 7 and 8).

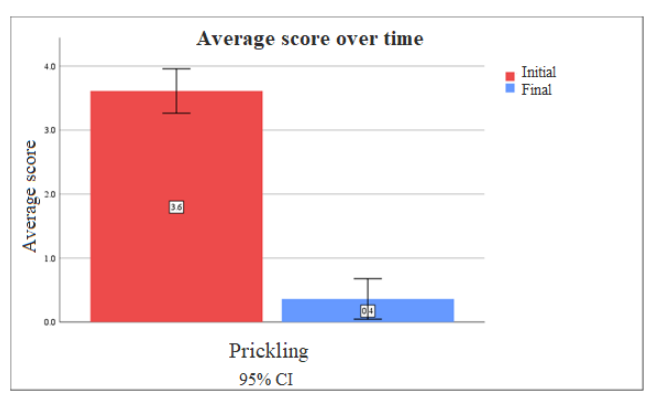

Figure 5.

Scores for prickling

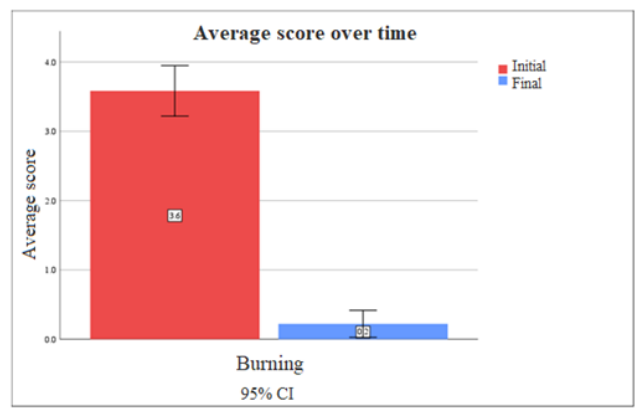

Figure 6.

Scores for burning sensation

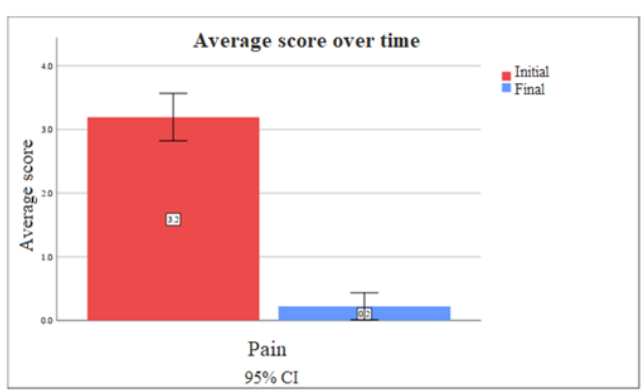

Figure 7.

Scores for pain 
FARMACIA, 2021, Vol. 69, 5

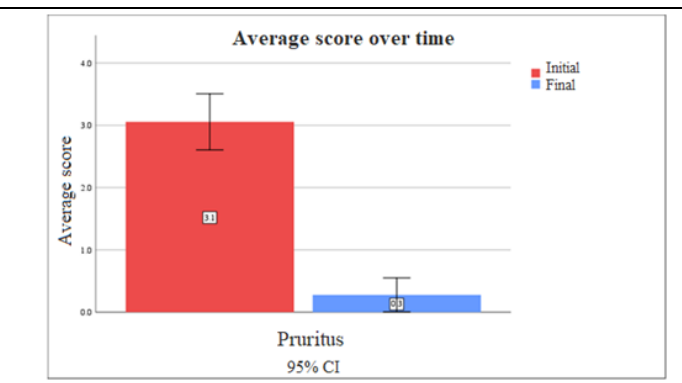

Figure 8.

Scores for pruritus

\section{Tolerance and acceptance}

As such, $76.5 \%$ of patients appreciated that the tested barrier cream has a very good efficacy, and $23.5 \%$ of the patients declared that the product has a good efficacy (Figure 9). All patients (100\%) tolerated the test cream very well and no adverse or discomfort was reported. The medical staff expressed an interest in using it further at their workplace.

The vehicle of the barrier cream is a good moisturizer and through its ingredients (glycerin, Shea butter, soybean oil and other solid lipids) is capable of positively influence the skin status. The emphasis should not be laid only on the primarily ingredients (Mimosa extract), but on the moisturizers and other protective ingredients in the composition and on the regular, correct application of the product in order for it to be effective.

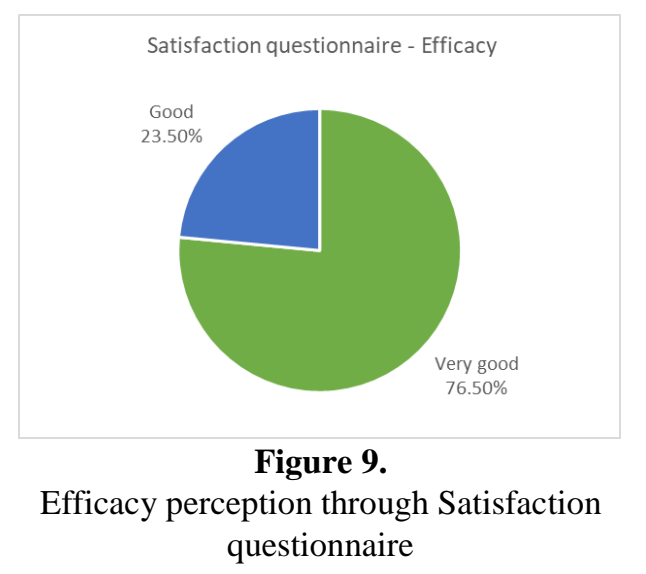

Irritant contact dermatitis is caused by acute and/or cumulative exposure to irritants in the home and work environments, for example soaps, detergents, water and friction. This leads to stratum corneum damage and impairment of the skin barrier. The development of irritant contact dermatitis can be avoided by preventive measures. Prophylactic measures, however, such as the use of moisturizers by workers in wet-work occupations, may reduce the risk of developing irritant contact dermatitis [17].

Earlier studies have suggested that moisturizers help to re-establish normal skin physiology in various diseases characterized by abnormal barrier function and may be effective in the prevention of contact and occupational irritant dermatitis [18], but the penetration is strongly dependent on the pathological process intended to be treated, particularly on the degree of alteration of stratum corneum $[19,20]$.

Several other reports support the role of moisturizers in preventing irritant contact dermatitis. Miyazaki Y et al. demonstrated the skin protective properties of a breathable ointment for the prevention of moisture associated skin damage intended to be used in healthcare settings [21]. In 2020, The American Contact Dermatitis Society reviewed best hand hygiene practices to mitigate COVID-19 related skin disease and concluded that: the higher frequency of hand washing in contrast with the lower frequency of moisturizer application provides an imbalance that predisposes to an increased risk of hand dermatitis and barrier creams and regular moisturizing lotions have been shown to be equivocal in the prevention of ICD. A combination of these products is effective to replenish skin barrier integrity and function [22].

Besides lipid emollients, humectants are added to formulations to attract and retain water into stratum corneum. Glycerol, component of the tested barrier cream, is a widely used humectant due to its multiple activities, thoroughly described in literature. Particularly glycerol plays an important role in maintaining the appropriate osmolarity in the intracellular environment and the liquid crystalline structure of the membranes [23].

The key ingredient of the barrier cream tested is Mimosa tenuiflora bark extract, etnobotanically used in Central and South America as remedy to treat skin burns and wounds and to prevent inflammation [24]. Mimosa tenuiflora bark was the subject of several studies evaluating its chemical and pharmacognostic characteristics $[9,25,26]$.

Zippel et al. separated an extract (consisting in ethanol precipitated compounds) fractionated then into an untypical arabinogalactan protein and an arabinogalactan polysaccharide. Both polymers were potent stimulators of dehydrogenase activity and proliferation of skin fibroblasts. This suggests that the arabinogalactancarbohydrate structure plays an important role in physiological activity of the Mimosa tenuiflora within wound healing. Fibroblasts react with a strong improvement of viability and proliferation in the presence of arabinogalactan polymers, indicating that the primary cellular target of Mimosa tenuiflora compounds are the fibroblasts within the connective tissue [27].

A randomised, placebo-controlled, double blind clinical trial was conducted to determine the effectiveness of a hydrogel containing Mimosa tenuiflora extract, with a high content of polyphenols, as treatment of severe skin ulcer. The study failed to provide statistically relevant data on the wound healing compared with 
controls, but showed a high cicatrisation potential of the extract [15].

The results of our study showed a statistically significant decrease in xerosis $(\mathrm{p}=0.00018)$, erythema $(\mathrm{p}=0.00018)$, scaling $(\mathrm{p}=0.00018)$ and cracking $(p=0.00017)$ from baseline to day 7 , as measured by the implemented scoring system, in subjects applying the provided barrier cream twice/ day after repeatedly washing and disinfecting their hands. It can be hypothesised that the positive effects observed after cream application are most likely related to the beneficial effects of moisturizing products on the hydration state and barrier function of the upper skin layers and on the healing properties of Mimosa tenuiflora extract.

ICD is a readily treatable condition and should not cause any deviation of proper hand hygiene. In irritant contact dermatitis, the management strategies are selection of less irritating hand hygiene products, frequent use of moisturisers to rebuild the skin barrier and education on proper hand hygiene practices [28].

\section{Conclusions}

For the patients enrolled in this study, ICD was most frequently caused by the long-term aggressive action of disinfectant products, followed by the use of latex gloves.

This study was focused on assessing the antiinflammatory effect (signs and symptoms) of a barrier cream containing Mimosa tenuiflora extract on skin damaged by ICD.

The study was also meant to indirectly prove the capacity of the barrier cream also containing natural biopolymers (galactan and galactomannan), Shea butter, glycerin, alpha-bisabol to isolate the skin exposed to the aggressive action of irritative factors, and directly the capacity of the product to repair skin affected by ICD.

As expected, both the physician - as objective surveyor, as well as the patients - as subjective response, reported a reduction of the Average Scores in this trial for the inflammatory and noninflammatory parameters.

The physician noticed a statistically significant reduction of xerosis, erythema, scaling and cracking of the skin after the application for 7 days of the provided barrier cream twice a day.

Patients also reported a significant reduction of the prickling and burning sensation, pain and pruritus. Both the patients and the physician were very satisfied with the product's efficacy and reported excellent tolerability.

The tested barrier cream is a great option to be used for both the dermato-cosmetic treatment of ICD, due to its anti-inflammatory and damaged skin repair properties, as well as for its preventive effect against contact dermatitis (irritative and/or allergic), due to the product's film properties that isolate and prevent the penetration of irritative agents, allergens and particulate pollutants.

The positive effects generated by the tested barrier cream are mainly explained by the action of various components (tannins, lactones, flavonoids, saponins and many oligo-elements having anti-inflammatory, analgesic and antiseptic effect) of its key ingredient, Mimosa tenuiflora.

\section{Conflict of interest}

The authors declare no conflict of interest.

\section{References}

1. Judge MR, Griffiths HA, Basketter DA, White IR, Rycroft RJ, McFadden JP, Variation in response of human skin to irritant challenge. Contact Dermatitis, 1996; 34: 115-117.

2. Tan $\mathrm{CH}$, Rasool S, Johnston GA, Contact dermatitis: allergic and irritant. Clin Dermatol., 2014; 32: 116-124.

3. Islam MT, Salehi B, Karampelas O, Sharifi-Rad J, Docea AO, Martorell M, Calina D, High skin melanin content, vitamin D deficiency and immunity: potential interference for severity of COVID-19. Farmacia, 2020; 68(6): 970-983.

4. Kiely LF, Moloney E, O'Sullivan G, Eustace JA, Gallagher J, Bourke JF, Irritant contact dermatitis in healthcare workers as a result of the COVID-19 pandemic: a cross-sectional study. Clin Exp Dermatol., 2021; 46(1): 142-144.

5. Zuo Y, Hua W, Luo Y, Li L, Skin reactions of N95 masks and medial masks among health-care personnel: a self-report questionnaire survey in China. Contact Dermatitis, 2020; 83: 145-147.

6. Chiriac AE, Coroaba A, Chiriac A, Pinteala M, Profire L, Profire B, Azoicăi D, A follow-up study of the occupational hand eczema and skin damage risk in healthcare providers from Romania in time of Covid-19. Farmacia, 2020; 68(4): 606-611.

7. Genis $\mathrm{M}, \mathrm{El}$ àrbol de la piel. Informacion Cientifica y Tecnologica, 1987; 135: 12-14.

8. Dweck AC, Paper to the Society of Cosmetic science, 2001, https://citeseerx.ist.psu.edu/viewdoc/ download?doi=10.1.1.614.2292\&rep=rep1\&type=pdf.

9. Anton R, Jiang Y, Weniger B, Beck J.P, Rivier L, Pharmacognosy of Mimosa tenuiflora (Willd.) Poiret. J Ethnopharmacol., 1993; 38: 153-157.

10. Jiang YL, Massiot G, Lavaud C, Teulon JM, Guechot C, Haag-Berrurier M, Anton R, Triterpenoid glycosides from the bark of Mimosa tenuiflora. Phytochemistry, 1991; 30: 2357-2360.

11. Leite SC de M, Medeiros CIS, Maia PCGGS, Magalhaes MIS, Freitas FOR, Pessoa H de LF, Nogueira TB de S, de Morais AMB, Mazzaro VD de M, Brustein VP, Filho GG de A, Antibacterial and hemolytic activities of Mimosa tenuiflora (Willd) Poir. (Mimosoidea). Afr J of Microbiol Res., 2015; 9(42): 2166-2171.

12. Lozoya X, Navarro V, Arnason Jt, Kourany E, Experimental evaluation of Mimosa tenuiflora (willd.) poir. (Tepescohuite) I. Screening of the antimicrobial 
properties of bark extracts. Arch Invest Med., 1989; 20: 87-93.

13. Mucci M, Sciocchetti M, Benvenuti C, Clinical efficacy and Safety of Mimosa tenuiflora Bark Extract in the Rhagades of the Nipple. Giorn It Ost Gin., 2006; 28(3): 106-114.

14. Hernandez C, Cadenillas L, Maghubi AE, Caceres I, Durrieu V, Mathieu C, Bailly JD, Mimosa tenuiflora Aqueous Extract: Role of Condensed Tannins in Anti-Aflatoxin B1 Activity in Aspergillus flavus. Toxins, 2021; 13(6): 391: 1-16.

15. Rivera-Arce E, Chávez-Soto MA, Herrera-Arellano A, Arzate S, Agüero J, Feria-Romero IA, Cruz-Guzmán A, Lozoya X, Therapeutic effectiveness of a Mimosa tenuiflora cortex extract in venous leg ulceration treatment. J. Ethnopharmacol., 2007; 109(3): 523-528.

16. Valencia-Gómez LE, Martel-Estrada SA, VargasRequena C, Rivera-Armenta JL, Alba-Baena N, Rodríguez-González C, Olivas-Armendáriz I, Chitosan/ Mimosa tenuiflora films as potential cellular patch for skin regeneration. Int J Biol Macromol., 2016; 93(Pt A): 1217-1225.

17. Loffler H, Effendy I, Prevention of irritant contact dermatitis. Eur J Dermatol., 2002; 12: 4-9.

18. Williams C, Wilkinson SM, McShane P, Lewis J, Pennington D, Pierce S, Fernandez C, A doubleblind, randomized study to assess the effectiveness of different moisturizers in preventing dermatitis induced by hand washing to simulate healthcare use. Br J Dermatol., 2010; 162(5): 1088-1092.

19. Ciolan DF, Mînea A, Andrieș A, Nicoară AC, Miron DS, The influence of compendial cells design and experimental setup on the in-vitro similarity of ketoconazole topical creams. Farmacia, 2015; 63(6): 865-871.

20. Popa LG, Giurcaneanu C, Mihai MM, Beiu C, Orzan OA, Negoita S, Burcea M, Turlea RI, Enachescu CI, The use of cadaveric skin allografts in the management of extensive wounds. Rom J Leg Med., 2021; 29(1): 37-44.

21. Miyazaki Y, Asano M, Uchino T, Kagawa Y, Development of a Breathable Protective Ointment for Moisture-associated Skin Damage. Yakugaku Zasshi, 2019; 139(10): 1281-1284.

22. Rundle CW, Presley CL, Militello M, Barber C, Powell DL, Jacob SE, Atwater AR, Watsky KL, Yu J, Dunnick CA, Hand hygiene during COVID-19: Recommendations from the American Contact Dermatitis Society. J Am Acad Dermatol., 2020; 83(6): 1730-1737.

23. Moldovan ML, Ionuț I, Bogdan C, Cosmetic products containing natural based emollients for restoring impaired skin barrier: formulation and in vivo evaluation. Farmacia, 2021; 69(1): 129-134.

24. Grether R, Note on the identity of tepescohuite in Mexico. Boletín de la Sociedad Botánica de México, 1988; 48: 151-152, (available in Spanish).

25. Amariz IAE, Pereira ECV, Alencar Filho JMT, Silva JPD, Souza NAC, de Oliveira AP, Rolim LA, Pereira RN, Chemical study of Mimosa tenuiflora barks. Nat Prod Res., 2020; 14: 1-5.

26. Meira CLC, Novaes CG, Novais FC, de Jesus VS, de Oliveira DM, Aguiar RM, Application of principal component analysis for the evaluation of the chemical constituents of Mimosa tenuiflora methanolic extract by DLLME/GC-MS. Microchem J., 2020; 152: doi: j.microc.2019.104284.

27. Zippel J, Deters A, Hensel A, Arabinogalactans from Mimosa tenuiflora (Willd.) Poiret bark as active principles for wound-healing properties: specific enhancement of dermal fibroblast activity and minor influence on HaCaT keratinocytes. J Ethnopharmacol., 2009; 124(3): 391-396.

28. Tan SW, Oh CC, Contact Dermatitis from Hand Hygiene Practices in the COVID-19 Pandemic. Ann Acad Med Singap., 2020; 49(9): 674-676. 